\title{
KEKUASAAN ALLAH DAN HUKUM ISLAM BAGI MANUSIA DAN ALAM
}

Oleh: ALI GENO BERUTU, MA. Hk

\author{
Makalah ini dibuat sebagai bahan ajar pegganti perkuliahan \\ pada Mata Kuliah Filsafat Hukum Islam \\ Program Studi Hukum Tata Negara (HTN) kelas A\&C \\ Fakultas Syariah IAIN Salatiaga
}

Tuhan, manusia, dan alam merupakan pembahasan filsafat klasik yang tidak pernah ada habisnya. Negeri-negeri seperti Mesir, India, Cina, Jepang, Iran, Babilonia, Yunani, dianggap sebagai rujukan dalam mempelajari konsep tersebut. Para filosof kuno sampai filosof modern sudah banyak yang mengupas tentang hal ini. Manusia merupakan bagian dari alam semesta (kosmos) yang telah diciptakan oleh Allah SWT., dan sebagai abdiNya. Manusia diberikan kuasa oleh Tuhan untuk memanfaatkan, mengolah, dan menjaga potensi alam semesta yang telah diciptakan-Nya (khalifatullah). Dengan alam pula manusia berproses dan memperoleh pengetahuan dari Tuhan. Oleh karena itu membahas hubungan antara manusia, alam, dan Allah SWT sebagai pencipta tidak dapat dipisahkan. ${ }^{1}$

\section{A. Manusia Menurut Hukum Islam}

Manusia adalah makhluk paling sempurna yang pernah diciptakan oleh Allah swt. Kesempurnaan yang dimiliki manusia merupakan suatu konsekuensi fungsi dan tugas mereka sebagai khalifah di muka dumi ini. Al-Quran menerangkan bahwa manusia berasal dari tanah.

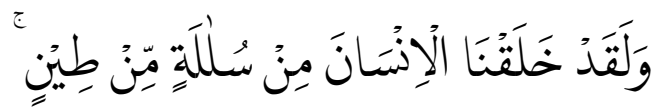

Dan sungguh, Kami telah menciptakan manusia dari saripati (berasal) dari tanah.

Membicarakan tentang manusia dalam pandangan ilmu pengetahuan sangat bergantung metodologi yang digunakan dan terhadap filosofis yang mendasari. Penganut teori psikoanalisis menyebut manusia sebagai homo volens (makhluk berkeinginan). Menurut aliran ini, manusia adalah makhluk yang memiliki perilaku interaksi antara komponen biologis (id), psikologis (ego), dan sosial (superego). Di dalam diri manusia tedapat unsur animal (hewani), rasional (akali), dan moral (nilai).

Sementara penganut teori behaviorisme menyebut manusia sebagai homo

\footnotetext{
${ }^{1}$ Samidi, Tuhan, Manusia dan Alam: Analisis Kitab Primbon Atassadhur Adammakna, SHAHIH Vol. 1, Nomor 1, Januari - Juni 2016, hal 14
} 
mehanibcus (manusia mesin). Behavior lahir sebagai reaksi terhadap introspeksionisme (aliran yang menganalisa jiwa manusia berdasarkan laporan subjektif dan (psikoanalisis) aliran yang berbicara tentang alam bawa sadar yang tidak nampak). Behavior yang menganalisis prilaku yang nampak saja. Menurut aliran ini segala tingkah laku manusia terbentuk sebagai hasil proses pembelajaran terhadap lingkungannya, tidak disebabkan aspek.

Penganut teori kognitif menyebut manusia sebagai homo sapiens (manusia berpikir). Menurut aliran ini manusia tidak di pandang lagi sebagai makhluk yang bereaksi secara pasif pada lingkungannya, makhluk yang selalu berfikir. Penganut teori kognitif mengecam pendapat yang cenderung menganggap pikiran itu tidak nyata karena tampak tidak memengaruhi peristiwa. Padahal berpikir, memutuskan, menyatakan, memahami, dan sebagainya adalah fakta kehidupan manusia. ${ }^{2}$

Sementara di dalam Al-Qur'an terdapat 4 kata atau istilah yang digunakan untuk menunjukkan manusia. Pertama, kata ins yang kemudian membentuk kata insan dan unas. Kata "insan" diambil dari kata "uns" yang mempunyai arti jinak, tidak liar, senang hati, tampak atau terlihat. Kata insan disebutkan dalam al-Qur'an sebanyak 65 kali, diantaranya (al-alaq/96: 5)

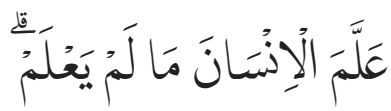

Dia mengajarkan manusia apa yang tidak diketahuinya.

\section{Konsep manusia secara jasmani}

Jasad (jisim) adalah substansi manusia yang terdiri atas stuktur organism fisik. Organisme fisik manusia lebih sempurna disbanding dengan organisme fisik makhluk- makhluk lain. Setiap makhluk biotik-lahiriah memiliki unsur material yang sama, yakni terbuat dari unsur tanah, api, udara dan air. Keempat unsur tersebut merupakan materi yang abiotik (mati). Ia akan hidup jika diberi energi kehidupan yang bersifat fisik (thaqah al-jismiyah).

Energi kehidupan ini lazimnya disebut dengan nyawa, karena nyawa hidup. Ibnu Maskawaih dan Abu al-Hasan al-Asy'ary menyebut energi tersebut dengan alhayah (daya hidup), sedang al-Ghazaliy menyebutnya dengan al-ruh jasmaniyah (ruh material). Dengan daya ini, jasad manusia dapat bernafas, merasakan sakit, panas-dingin, pahit-manis, haus-lapar, seks dan sebagainya. Al-hayat berbeda dengan al-ruh, sebab ia ada sejak adanya sel kelamin, sedang al-ruh menyatu dalam tubuh manusia setelah embrio berusia empat bulan dalam kandungan. Ruh bersifat substansi (jauhar) yang dimiliki manusia, sedang nyawa merupakan sesuatu yang baru $(a r a d b)$ yang juga dimiliki oleh hewan. ${ }^{3}$

${ }^{2}$ St. Rahmatiah, KONSEP MANUSIA MENURUT ISLAM, Al-Irsyad Al-Nafs, Jurnal Bimbingan Penyuluhan Islam Volume 2, Nomor 1 Desember 2015: 93-115

${ }^{3}$ Abdul Mujib, Jusuf Mudzakir. Nuansa-Nuansa Psikologi Islam (Cet. I; Jakarta: PT. Raja Grapindo Persada, 2001)., 40. 
Jisim manusia memiliki natur tersendiri. Al-Farabi menyatakan bahwa komponen ini dari alam ciptaan yang memiliki bentuk, rupa, berkualitas, berkadar, bergerak, dan diam, serta berjasad yang terdiri dari beberapa organ. Begitu juga alGazali memberikan sifat komponen ini dapat bergerak, memiliki rasa, berwatak gelap dan kasar, dan tidak berbeda dengan benda-benda lain. Sementara Ibnu Rusyd berpendapat bahwa komponen jasad merupakan komponen materi.

Ciri-ciri jasmani yaitu:

a. Bersifat materi yang tercipta karena adanya proses (tahap);

b. Adanya bentuk berupa kadar dan bisa disifati;

c. Ekstetensinnya menjadi wadah roh;

d. Terikat oleh ruang dan waktu

e. Hanya mampu menangkap yang kongkret bukan yang abstrak

f. Substansinya temporer dan hancur setelah mati

\section{Konsep manusia secara ruhani}

Ruh merupakan substansi psikis manusia yang menjadi esensi kehidupannya. Sebagian ahli menyebut ruh sebagai badan halus (jism lathif), ada yang substansi sederhana (jauhar basith), dan ada yang substansi ruhani (jauhar ruhani). Ruh yang menjadi pembeda antara esensi manusia dengan esensi makhluk lain. Ruh berbeda dengan spirit dalam terminilogi psikologi, sebab terminologi ruh memiliki arti jauhar (substance), sedang spirit lebih bersifat aradh (accident).

Istilah yang sering disebut dalam Al-Qur'an untuk menggambarkan unsur manusia yang bersifat rohani adalah ruh dan nafs. Tentang ruh dijelaskan dalam surah al-Hijr: 28-29 Allah berfirman:

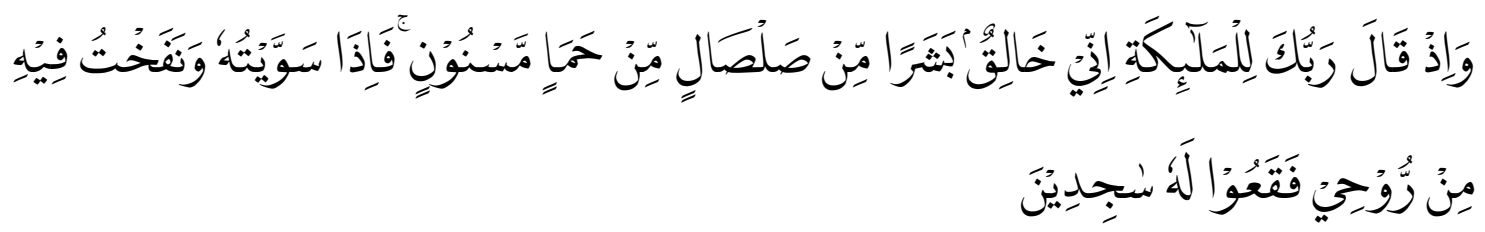

Dan (ingatlah), ketika Tuhanmu berfirman kepada para malaikat, "Sungguh, Aku akan menciptakan seorang manusia dari tanah liat kering dari lumpur hitam yang diberi bentuk. Maka apabila Aku telah menyempurnakan (kejadian)nya, dan Aku telah meniupkan roh (ciptaan)-Ku ke dalamnya, maka tunduklah kamu kepadanya dengan bersujud."

Sebagaimana yang digambarkan dalam ayat di atas, ruh adalah unsur terakhir yang dimasukkan ke dalam tubuh manusia, dengan demikian dapat diambil pemahaman bahwa ruh adalah unsur yang sangat penting karena merupakan unsur 
terakhir yang menyempurnakan proses penciptaan manusia. Ruh juga dikatakan sebagai bagian unsur yang mulia, hal ini tersirat dari perintah Allah kepada para malaikat (termasuk pula iblis) untuk sujud kepada manusia sebagai tanda penghormatan setelah dimasukkannya unsur ruh.

Dalam memahami sifat-sifat ruh, ada beberapa ulama dan para sarjana muslim yang mencoba memahaminya dengan berpijak pada disiplin ilmunya masingmasing, mereka di antaranya sebagai berikut:

a) Al-Qayyim, dan Al-Razy dan Hadi berpendapat bahwa ruh adalah suatu jisim (benda) yang sifatnya sangat halus dan tidak dapat diraba. Ruh merupakan jisim nurani yang tinggi dan ringan, hidup dan selalu bergerak menembus dan menjalar ke dalam setiap anggota tubuh bagaikan menjalarnya air dalam bunga mawar. Jisim tersebut berjalan dan memberi bekas-bekas seperti gerak, merasa, dan berkehendak. Jika anggota tubuh tersebut sakit dan rusak, serta tidak mampu lagi menerima bekas-bekas itu, maka ruh akan bercerai dengan tubuh dan pergi ke alam arwah. ${ }^{4}$

b) Al-Ghazali membagi ruh dalam dua pengertian. Pertama, ruh yang bersifat jasmani yang merupakan bagian dari tubuh manusia, yaitu zat yang amat halus yang bersumber dari relung hati (jantung), yang menjadi pusat semua urat (pembuluh darah), yang mampu menjadikan manusia hidup dan bergerak, serta merasakan ber-bagai rasa. Ruh ini dapat diibaratkan sebuah lampu yang mampu menerangi setiap sudut ruangan (organ tubuh). Ruh sering pula diistilahkan dengan nafs (nyawa). Kedua, ruh yang bersifat rohani yang merupakan bagian dari rohani manusia yang sifatnya halus dan gaib. Ruh ini memberikan kemampuan kepada manusia untuk mengenal diri-nya sendiri, mengenal Tuhannya, dan memperoleh serta menguasai ilmu yang bermacam-macam. Ruh pula yang menyebabkan manusia berperikemanusiaan dan berakhlak sehingga memjadikannya berbeda dengan binatang. ${ }^{5}$

c) Ansari menyatakan, salah satu kapasitas khusus yang hanya dimiliki oleh manusia dan tidak dimiliki oleh makhluk lain disebabkan karena adanya ruh adalah kemampuannya untuk memperoleh pengetahuan yang luas. Pernyataan Ansari tersebut didasarkan pada Al-Qur'an surah al-Baqarah/2: 31 yang artinya sebagai berikut:

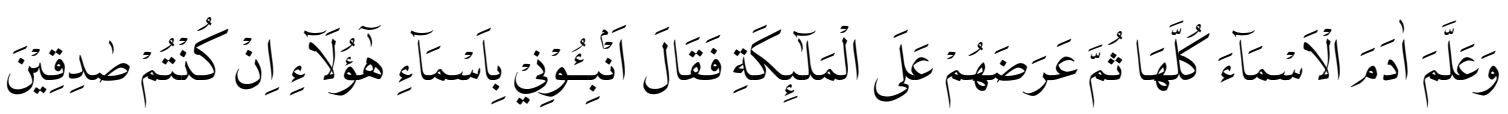

Dan Dia ajarkan kepada Adam nama-nama (benda) semuanya, kemudian Dia perlihatkan kepada para malaikat, seraya berfirman, "Sebutkan kepada-Ku nama semua (benda) ini,

\footnotetext{
${ }^{4}$ Al-Qayyim, Ruh. Terjemahan Syed Ahmad Semait. (Singapore: Pustaka Nasional Ltd, 1991)., 1

${ }^{5}$ Al-Ghazali, Ihya Al-Ghazali. Terjemahan Ismail Yakub (Jakarta: CV. Faizan, 1984)., 123
} 
jika kamu yang benar!”

Adam diajarkan oleh Allah swt berbagai nama-nama benda setelah unsur ruh ditiupkan kedalam tubuhnya, hal ini menyiratkan bahwa keberadaan unsur ruh menyebabkan manusia mempunyai kemampuan untuk menerima dan memperoleh pengetahuan yang luas.

d) Sedangkan menurut Arifin, keberadaan ruh pada diri manusia dapat menyebabkan tumbuh dan berkembangnya daging, tulang, darah, kulit, dan bulu, ruh pula yang menyebabkan tubuh manusia dapat bergerak, berketurunan, dan berkembangbiak. Di samping itu ruh pula yang membuat manusia dapat melihat, mendengar, merasa, berpikir, berkesadaran, dan berpengertian.

Di samping ruh, istilah lain yang dijumpai dalam Al-Qur'an untuk menamakan unsur rohani manusia ialah nafs. Ruh dan nafs adalah dua buah istilah yang pada hakikatnya sama.

Ciri-ciri rohani yaitu :

a. Adanya di alam arwah (immateri);

b. Tidak meiliki bentuk, kadar dan tidak bisa disifati;

c. Ada energi rohaniah yang disebut al-amanah;

d. Ekstitensi energi rohaniah tertuju pada ibadah;

e. Tidak terikat oleh ruang dan waktu;

f. Dapat menangkap beberapa bentuk konkret dan abstrak.

\section{Konsep manusia secara Substansi Nafsani}

Kata jiwa berasal dari bahasa Arab (النفس) atau nafs' yang secara harfiah bisa diterjemahkan sebagai diri atau secara lebih sederhana bisa diterjemahkan dengan jiwa, dalam bahasa Inggris disebut soul atau spirit.

Secara istilah kata jiwa dapat merujuk pada beberapa pandangan ulama dan filusuf muslim. Para filosof muslim-terutama al-Kindi, al- Farabi dan Ibn Sina umumnya sepakat mendefiniskan bahwa jiwa adalah "kesempurnaan awal bagi fisik yang bersifat alamiah, mekanistik dan memiliki kehidupan yang energik." Secara lebih rinci yang dimaksudkan 'kesempurnaan awal bagi fisik yang bersifat alamiah' adalah bahwa manusia dikatakan menjadi sempurna ketika menjadi makhluk yang bertindak. Sebab jiwa merupakan kesempurnaan pertama bagi fisik alamiah dan bukan bagi fisik material. Kemudian makna 'mekanistik' adalah bahwa badan menjalankan fungsinya melalui perantara alat-alat, yaitu anggota tubuhnya yang bermacam-macam. Sedangkan makna 'memiliki kehidupan yang energik' adalah bahwa di dalam dirinya

${ }^{6}$ Muhammad Ali Abu Rayyan, Tarikh al-Fikr al-Falsafi fil Islam, (Iskandariyah, Dar al-Jami'at alMishriyah, 1984), 337. 
terkandung kesiapan hidup dan persiapan untuk menerima jiwa. ${ }^{7}$

Di dalam Al-Qur'an ditemukan tiga buah istilah yang dikaitkan dengan kata nafs, yaitu al-nafs al-mutma'innah seperti yang terdapat dalam surah al-Fajr ayat 27, al-nafs al- lawwamah seperti yang terdapat dalam surah al-Qiyaamah ayat 2, dan alnafs laammaratun bi al-su' seperti yang terdapat dalam surah Yusuf ayat 53. Ketiga buah istilah yang dikaitkan dengan kata nafs tersebut menyiratkan adanya tiga buah pembagian kualitas unsur rohani yang terdapat pada manusia.

Al-nafs al-mutma 'innah secara etimologi berarti jiwa yang tenang, dinamakan jiwa yang tenang karena dimensi jiwa ini selalu berusaha untuk meninggalkan sifatsifat tercela dan menumbuhkan sifat-sifat yang baik sehingga memperoleh ketenangan. Dimensi jiwa ini secara umum dinamakan qalb atau hati. ${ }^{8}$

Al-nafs al-lawwamah secara literlik berarti jiwa yang amat menyesali dirinya sendiri, maksudnya bila ia telah berbuat kejahatan maka ia menyesal telah melakukan perbuatan tersebut, dan bila ia berbuat kebaikan maka ia juga menyesal kenapa tidak berbuat lebih banyak. Dimensi jiwa ini dinamakan oleh para filosof Islam sebagai akal.

Al-nafs laammaratun bi al-su' secara harfiah berarti jiwa yang memerintah kepada kejahatan, yaitu aspek jiwa yang menggerakkan manusia untuk berbuat jahat dan selalu mengejar kenikmatan. Menurut para kaum sufi, dimensi jiwa ini dinamakan sebagai hawa atau nafsu.

Ahmad menyebutkan, meskipun unsur rohani manusia yang diistilahkan dengan nafs disebut dengan tiga buah istilah yang berbeda-beda sehingga seolah-olah ketiganya berdiri sendiri-sendiri, namun hakikat ketiganya merupakan satu kesatuan. Ketiga buah istilah tersebut menggambarkan bahwa secara garis besar terdapat tiga buah fungsi dan sifat yang dimainkan oleh unsur rohani manusia. ${ }^{9}$

Dari pendapat beberapa ulama dan sarjana muslim di atas, dapat diambil simpulan bahwa meskipun Al-Qur'an menggunakan istilah yang berbeda-beda dalam menggambarkan unsur rohani manusia, yaitu ruh dan nafs, namun unsur-unsur rohani tersebut hakikatnya satu, disebut dengan istilah yang berbeda adalah untuk membedakan sifat-sifat rohani manusia. Keberadaan unsur rohani tersebut menyebabkan manusia dapat hidup dan bergerak, berpikir, merasa dan menyadari keberadaan dirinya, bahkan menyadari akan keberadaan sesuatu yang menciptakan dirinya, yaitu Tuhan.

Ciri-ciri nafsani yaitu:

a. Adanya di alam jasad dan rohani terkadang tercipta dengan proses bisa juga tidak

${ }^{7}$ Mahmud Qasim, Fi an-Nafs wa al-'Aql li Falasifah al-'Ighriq wa al-Islam, cet. IV, (Kairo: Maktabah al-Injilu al-Mishriyah, 1969), 73-74.

${ }^{8}$ A. Mujib, Fitrah \& Kepribadian Islam: Sebuah Pendekatan Psikologis (Jakarta: Darul Falah, 1999), tth.

${ }^{9}$ A. Ahmad, Qur'anic Concept of Human Psyche (Islamabad: Islamic Research Institute Press, 1992)., th. 
b. Antara berbentuk atau tidak

c. Memiliki energy rohaniyah dan jismiyyah

d. Ekstitensi energy nafsani tergantung ibadah dan gizi (makanan)

e. Ekstitensi realisasi atau aktualisasi diri

f. Antara terikat atau tidak oleh ruang dan waktu

g. Dapat menangkap antara yang konkret dan abstrak Antara dapat dibagi-bagi atau tidak

Manusia adalah salah satu makhluk ciptaan Allah SWt yang memiliki peranan penting dalam kehidupan di muka bumi. Manusia juga dipandang sebagai makhluk yang paling tinggi derajatnya dibandingkan makhluk Allah SWT bahkan Allah menyuruh para malaikat untuk bersujud kepada Adam Alaihi salam. Masyarakat barat memiliki pandangan bahwa manusia adalah makhluk yang memiliki jiwa dan raga serta dibekali dengan akal dan pikiran. Lalu bagaimanakah hakikat manusia dalam pandangan islam? Simak penjelasan berikut ini:

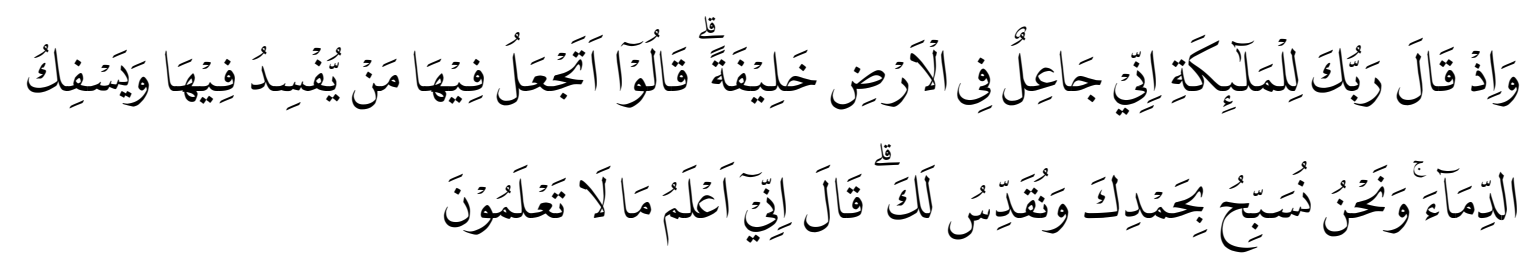

Dan (ingatlah) ketika Tuhanmu berfirman kepada para malaikat, "Aku hendak menjadikan khalifah di bumi." Mereka berkata, "Apakah Engkau hendak menjadikan orang yang merusak dan menumpahkan darah di sana, sedangkan kami bertasbih memujiMu dan menyucikan nama-Mu?" Dia berfirman, "Sungguh, Aku mengetahui apa yang tidak kamu ketahui.",

Adapun tujuan utama Allah SWT menciptakan manusia adalah agar manusia dapat menjadi khalifah atau pemimpin di muka bumi. Tugas utama manusia adalah beribadah dan menyembah Allah SWt, menjalani perintahnya serta menjauhi larangannya. Sebagaimana disebutkan dalam firman Allah SWT berikut ini

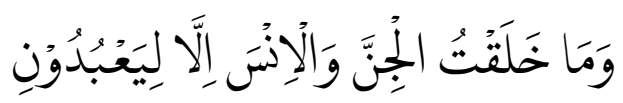

Aku tidak menciptakan jin dan manusia melainkan agar mereka beribadah kepada-Ku.

Dalam Islam beberapa peranan yang merupakan hakikat diciptakannnya manusia. Berikut ini adalah beberapa dimensi hakikat penciptaan manusia berdasarkan pandangan Islam. 


\section{Sbagai Hamba Allah}

Hakikat manusia yang utama adalah sebagai hamba atau abdi Allah SWT. Sebagai seorang hamba maka manusia wajib mengabdi kepada Allah SWT dengan cara menjalani segala perintahnya dan menjauhi segala larangannya. Sebagai seorang hamba, seorang manusia juga wajib menjalankan ibadah seperti shalat wajib, puasa ramadhan, zakat, haji dan melakukan ibadah lainnya dengan penuh keikhlasan dan segenap hati sebagaimana yang disebutkan dalam ayat berikut ini

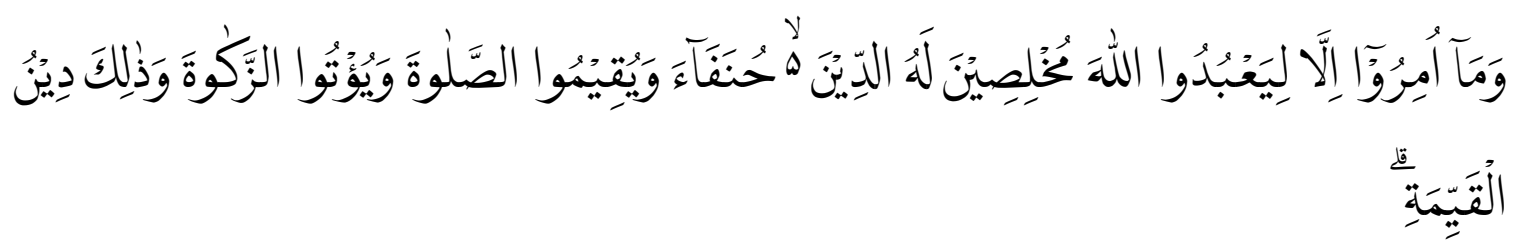

Padahal mereka hanya diperintah menyembah Allah dengan ikhlas menaati-Nya sematamata karena (menjalankan) agama, dan juga agar melaksanakan salat dan menunaikan zakat; dan yang demikian itulah agama yang lurus (benar).

\section{Sebagai al-Nas}

Dalam Al-Qur'an manusia juga disebut dengan al-nas. Kata al-nas dalam AlQur'an mengacu pada hakikat manusia dalam hubungannya dengan manusia lain atau dalam masyarakat. Manusia sebagaimana disebutkan dalam ilmu pengetahuan, adalah makhluk sosial yang tidak dapat hidup tanpa keberadaan manusia lainnya Sebagaimana yang dijelaskan dalam firman Allah SWT berikut.

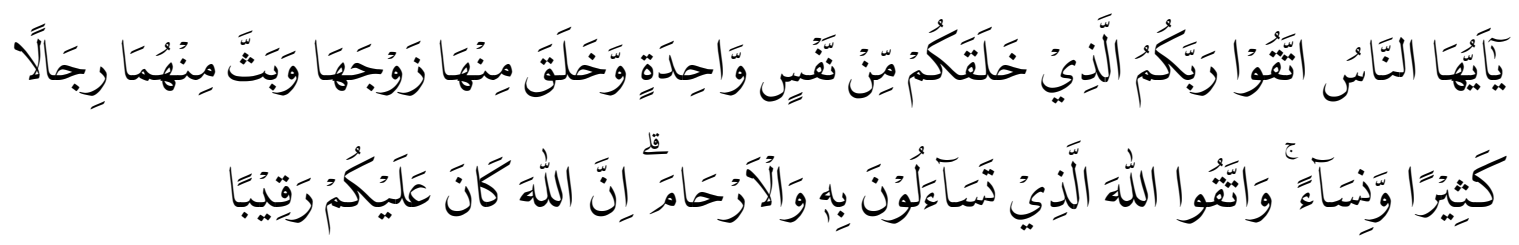

Wahai manusia! Bertakwalah kepada Tuhanmu yang telah menciptakan kamu dari diri yang satu (Adam), dan (Allah) menciptakan pasangannya (Hawa) dari (diri)-nya; dan dari keduanya Allah memperkembangbiakkan laki-laki dan perempuan yang banyak. Bertakwalah kepada Allah yang dengan nama-Nya kamu saling meminta, dan (peliharalah) hubungan kekeluargaan. Sesungguhnya Allah selalu menjaga dan mengawasimu.

\section{Sebagai khalifah Allah}

Manusia adalah mahkluk sentral di Planet ini. Selain penciptaannya yang paling sempurna dan seimbang, mahkluk-mahkluk lain yang ada seperti hewan dan tumbuhtumbuhan diciptakan untuk kepentingannya, baik secara langsung maupun tidak langsung. 
Hak pemakmuran dan pengelolaan bumi beserta isinya diberikan kepada manusia sebagai konsekuensi logis atas kesediaannya memangku amanah Allah. ${ }^{10}$

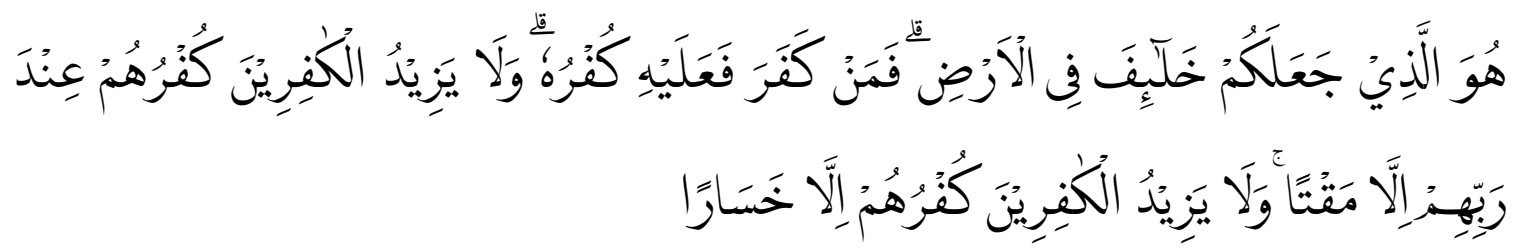

Dialah yang menjadikan kamu sebagai khalifah-khalifah di bumi. Barangsiapa kafir, maka (akibat) kekafirannya akan menimpa dirinya sendiri. Dan kekafiran orang-orang kafir itu hanya akan menambah kemurkaan di sisi Tuhan mereka. Dan kekafiran orangorang kafir itu hanya akan menambah kerugian mereka belaka.

Dalam konsep Islam, manusia adalah khalifah yakni sebagai wakil, pengganti atau duta tuhan di muka bumi. Dengan kedudukannya sebagai khalifah Allah swt dimuka bumi, manusia akan dimintai tanggungjawab dihadapannya. Tentang bagaimana ia melaksanakan tugas suci kekhalifahannya. Oleh sebab itu dalam melaksanakan tanggungjawab itu manusia dilengkapi dengan berbagai potensi seperti akal pikiran yang memberikan kemampuan bagi manusia berbuat demikian. ${ }^{11}$

Kata khalifah juga mengandung makna pengganti nabi Muhammad saw dalam fungsinya sebagai kepala Negara, yaitu pengganti Nabi Saw dalam jabatan kepala pemerintahan dalam Islam baik urusan agama maupun dunia.

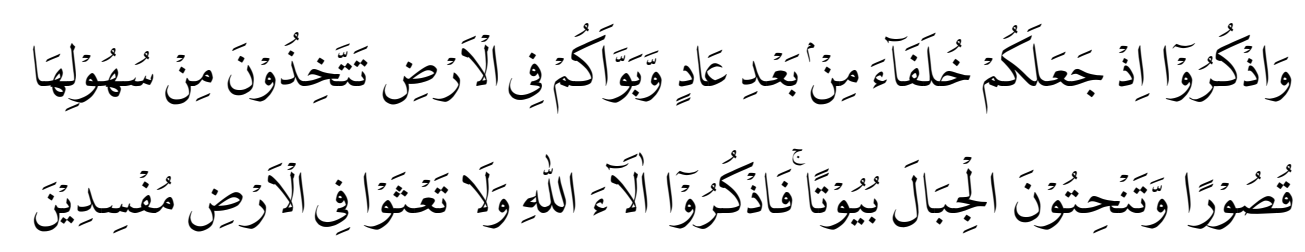

Dan ingatlah ketika Dia menjadikan kamu khalifah-khalifah setelah kaum 'Ad dan menempatkan kamu di bumi. Di tempat yang datar kamu dirikan istana-istana dan di bukit-bukit kamu pahat menjadi rumah-rumah. Maka ingatlah nikmat-nikmat Allah dan janganlah kamu membuat kerusakan di bumi. (QS. Al-A'raf: 47).

Kesimpulan besar dari Tujuan penciptaan manusia yang dapat kita Tarik dalam makalah singkat ini adalah:

1. Tujuan penciptaan manusia pertama adalah untuk mengabdi dan menghambakan diri kepada Allah SWT (ibadah). Tujuan ini mendidik manusia untuk senantiasa meningkatkan keimanan dan ketaqwaan kepada Allah SWT, karena ibadah dapat dikatakan sempurna apabila dilaksanakan atas dasar landasan iman kepadaNya.

${ }^{10}$ Lajnah Pentashihan Mushaf Al-Qur'an, Tafsir Al-Qur'an Tematik (Spritualitas dan Ahklak), (Jakarta: Aku Bisa, 2012), 37.

${ }^{11}$ Dewan Redaksi Ensiklopedi Islam, Ensiklopedi Islam Jiid 3, (Jakarta, PT Ichtiar Baru van Hoeve, 2003), 35 
Semakin tinggi tingkat keimanan seseorang, maka semakin tinggi pula kualitas ibadah yang dilakukan. Allah SWT dan RasulNya memerintahkan seseorang untuk senantiasa meningkatkan dan memperbaharui keimanan, karena iman dapat mengalami pasang naik maupun pasang surut.

2. Tujuan penciptaan manusia yang kedua adalah Allah menempatkan manusia sebagai khalifah fi al-ardh, yaitu manusia yang diberi derajat tinggi untuk mengatur, mengelola dan mengolah semua potensi yang ada dimuka bumi. Keadaan ini mendidik manusia untuk selalu berfikir kearah pengembangan pengelolaan seluruh potensi yang ada sehingga tercipta sumber daya manusia (SDM) yang professional. Terpilihnya manusia sebagai pemimpin di muka bumi mendidik mereka untuk memberikan takaran yang seimbang bagi manusia itu sendiri bahwa di satu sisi ia harus bertanggungjawab terhadap dirinya, masyarakat dan alam semesta, dan di sisi lain ia tidak dapat melepaskan dirinya sebagai hamba yang harus patuh terhadap cosmos Ilahiyyah. ${ }^{12}$ Tarbiyah Ijtimaiyah (pendidikan kemasyarakatan) yang baik adalah orang yang selalu memperhatikan perasaan orang lain. Seorang muslim dalam masyarakat tidak dibenarkan menyakiti saudaranya walaupun hanya dengan menebar bau yang tidak enak. Ibnu Qayyim berpendapat, tidak cukup hanya tanpa menyakiti perasaan saja, seorang muslim harus mampu membahagiakan dan menyenangkan hati saudara-saudara di sekitarnya. $^{13}$

3. Tujuan penciptaan manusia yang ketiga adalah mengemban amanah, yaitu kesanggupan manusia memikul beban taklif yang diberikan oleh Allah SWT. Hal ini mendidik orang-orang beriman supaya selalu memelihara amanah dan mematuhi perintah tersebut. Amanah yang sudah ditetapkan tersebut agar tidak dikhianati, baik amanah dari Allah SWT dan RasulNya maupun amanah antara sesama manusia. Di samping itu, manusia juga dididik untuk bertanggungjawab atas segala perbuatannya. Karena kelak di akhirat akan dihisab untuk menerima imbalan pahala atau balasan azab. Tidak ada seorang pun dapat menggantikan kedudukan orang lain untuk mempertanggungjawabkan perbuatannya, dan tak seorang pun lolos tanpa pembalasan. ${ }^{14}$

\section{B. Konsep tentang Alam Semesta}

Konsepsi tentang alam mengandung arti kosmogoni (asal-usul alam semesta) dan ada kaitannya dengan masalah identifikasi. Tidak seperti konsepsi indera, yang lazim dimilikimanusia dan makhluk hidup lainnya identifikasi ini hanya di miliki oleh manusia. Karena itu, konsepsi tentang alam semesta juga hanya di miliki oleh manusia. Konsepsi

${ }^{12}$ Inong Satriadi, Tujuan Penciptaan Manusia dan Nilai Edukasinya (Kajian Tafsir Tematis), Ta 'dib Volume. 12, No. 1 (Juni 2009), 40

${ }^{13}$ Armai Arief, Reformulasi Pendidikan Islam, (Jakarta: CRSD Press, 2005), 166.

${ }^{14}$ Aisyah Bintu Syati, Manusia dalam Perspektif al-Quran, Penterjemah: Ali Zawawi, judul asli: Maqal fi al-Insan, Dirasah Quraniyyah, (Jakarta: Pustaka Firdaus, 1999), 95. 
ini bergantung pada pemikiran dan pemahamannya. Dari persepsi indera tentang alam semesta banyak bintang ang lebih maju ketimbang manusia, karena bintang memiliki indera tertentu yang tidak di miliki oleh manusia.

Pada umumnya ada tiga macam konsepsi tentang alam semesta atau identifikasi tentang alam semesta atau dengan kata lain interpretasi manusia tentang alam semesta. Sumber interpretasi ini ada tiga hal: Ilmu pengetahuan, filsafat, agama. Maka dapat dikatakan bahwa ada tiga macam konsepsi tentang alam semesta: konsepsi ilmiah, konsepsi filosofis dan konsepsi religious.

1. Konsepsi ilmiah tentang alam semesta

Ilmu pengetahuan dapat memberikan manusia tentang sesuatu serta memperkenalkan manusia dengan hukum tertentu yang mengatur sesuatu. Dengan demikian ilmu pengetahuan mampu membuat manusia dapat mengendalikan dan memanfaatkan sesuatu. Adapun peran ilmu pengetahuan dalam kehidupan manusia adalah:

a. Dapat menjawab pertanyaan penting mengenai alam semesta sebagai keseluruhan;

b. Dapat menjadi konsepsi abadi dan andal bukan konsepsi yang sifatnya untuk semestara waktu;

c. Dapat memiliki nilai teorotis dan nilai realistis juga bukan semata-mata nilai praktis dan nilai teknis saja.

Konsepsi alam semesta menurut Islam adalah Islam membawakan tauhid dalam bentuknya yang paling murni. Dari sudut pandang Islam, tidak ada yang seperti Allah swt dan tidak ada yang menyamainya. Independensi Allah mutlak sifatnya, Segala sesuatu bergantung pada-Nya, namun Dia tidak bergantung pada apa dan siapa.

Dari sudut pandang tauhid dan konsepsi Islam tentang alam semesta merupakan ciptaan dan diurus oleh kehendak dan perhatian Allah SWT. Jika Allah sekejap saja tidak memberi perhatian maka seluruh alam semesta akan binasa seketika itu juga. Segala yang diciptakan Allah tidaklah sia-sia. Sistem yang ada pada alam semesta adalah system yang paling sempurna. Sistem ini memanifestasikan keadilan dan kebenaran dan didasarkan pada serangkaian sebab akibat. Takdir Allah berlaku untuk alam semesta. Manusia ditakdirkan oleh takdir Allah untuk merdeka dan bertanggung jawab. Manusia adalah tuhan bagi nasibnya sendiri dan manusia memiliki harkat dan martabat khususnya. Manusi tempat untuk menjadi khalifah di alam semesta yang telah diciptakan Allah SWT.

2. Pandangan filosofis mengenai alam semesta

Meskipun konsepsi filosofis megenai alam semesta tidak seksama dan spesifik konsepsi ilmu pengetahuan, namun konsepsi filosofis didasarkan pada sejumlah prinsip yang jelas dan tidak disaangka oleh akal. Prinsip ini mempengaruhi reaksi manusia terhadap pengalamannya berhubungan dengan alam. Prinsip ini menentukan sikapnya dan memberinya pandangan tertentu mengenai alam semesta, meberikan makna kepada 
kehidupannya atau menariknya kearah hal-hal yang sepele dan tak masuk akal. Itulah sebabnya ilmu pengetahuan tak dapat memberikan konsepsi tentang alam yang dapat menjadi dasar bagi ideology, sementara filsafat dapat mnguraikannya.

3. Konsepsi religious mengenai alam semesta

Dalam agama-agama tertentu seperti Islam konsep religious tentang alam semesta mengambil warna filosofis atau argumentative dan merupakan bagian integral dari agama itu sendiri. Pertanyaan-pertanyaan yang diangkat oleh agama didasarkan pada pemikiran dan hujah. Dengan demikian konsepsi Islam mengenai alam semesta bersifat rasional dan filosofis. Selain nilai konsepsi filosofis yaitu abadi dan komprehensif, konsepsi religious tentang alam semesta tak seperti konsepsi ilmiah dan filosofis murni, memiliki satu lagi nilai yaitu menyucikan prinsip-prinsip konsepsi alam semsta.

\section{Proses Terbentuknya Alam Semseta}

Alam semesta di ciptakan secara sengaja bukan secara kebetulan, alam semesta tidak bersifat abadi, tetapi tercipta dalam waktu dengan sebuah titik awal. Proses terbentuknya alam semesta bisa dijelaskan dengan teori big bang dan ayat-ayat Al-Qur'an.

\section{Proses terbentuknya alam semesta menurut teori Big Bang}

Alam diciptakan dari tiada (creatio ex nibilo) meskipun ketiadaan ini tidak harus dipahami dalam arti ketiadaan yang mutlak, tetapi ada sebagai potensi atau kemungkinan. Adapun tentang awal mula terbentuknya alam semesta didukung oleh penemuan teori astrofisika modern disebut peristiwa Big Bang menurut teori ini alam semesta berkembang secara evolutif. ${ }^{15}$

Semua massa atau benda-benda yang akan membentuk alam semesta seperti: galaksi, bintang, semua nebula, gas Matahari, seluruh planet, satelit maupun zat-zat kosmos lainya, berkumpul menjadi satu di bawah tekanan yang paling tinggi dan sangat kuat. Sehingga menyebabkan pecah dan runtuh berantakan, jadi berkepingkeping. Kepingan tersebut akhirnya menjadi bintang-bintang, matahari, planet, satelit, galaksi nebula dan benda-benda semesta lainya bertaburan memenuhi ruang kosong. ${ }^{16}$

Teori Big Bang juga menjelaskan bahwa alam semesta berkembang dengan sangat cepat dalam beberapa mikrodetik yang pertama. Dimulai dengan kabut hidrogen yang berputar melanda dan alam semesta berkembang dari suatu materi yang terdiri atas proton, elektron dan neutron yang berada dalam lautan radiasi dengan suhu yang sangat tinggi. ${ }^{17}$ Ketika alam mengembang, suhu materi semakin turun sehingga terbentuk banyak helium, deuterium, dan unsur ringan lainya dialam semesta. Kondisi ini sesuai dengan kenyataan yang terjadi di jagat raya.

\footnotetext{
15 Toto Suharto, Filsafat Pendidikan Islam, (Jogjakarta: Ar-Ruzz, 2006), 46.

${ }^{16}$ Kurdi Ismail Haji ZA, Kiamat Menurut Ilmu Pengetahuan dan Al-Qur'an, (Jakarta: Pustaka Amani, 1996). 19

17 Jamali Sahroni, Filsafat Pendidikan Islam, (Bandung: 2011). h. 40-41.
} 
Alam dengan asap yang melimpah merupakan $90 \%$ dari semua materi kosmos ini. Dengan gerak acak awan seperti itu, atom-atom kadang bergabung secara kebetulan untuk membentuk kantong-kantong gas yang padat. Dari peristiwa ini muncul bintang-bintang, demikianlah secara perlahan setelah melalui kira-kira dua puluh miliar tahun, akhirnya terbentuklah galaksi-galaksi yang terus berkembang, juga bintang-bintang, matahari serta planet planet yang mengitari bumi yang dihuni manusia. Inilah sebuah sistem planet dengan matahari sebagai pusatnya yang disebut tata surya. Permulaan alam seperti ini dalam filsafat Islam disebut gerak transuptansial yaitu gerak alam yang bukan horisontal, melainkan vertikal ke arah yang lebih sempurna.

\section{Proses terbentuknya alam semesta menurut Al-Qur'an}

Mengenai proses penciptaan alam semesta, Al-Qur'an telah menyebutkan secara gamblang mengenai hal tersebut, dan dapat dipahami bahwa proses penciptaan alam semesta menurut Al-Qur'an adalah secara bertahap. Hal ini dapat diketahui melalui firman Allah Swt dalam Surat Al-Anbiya ayat 30:

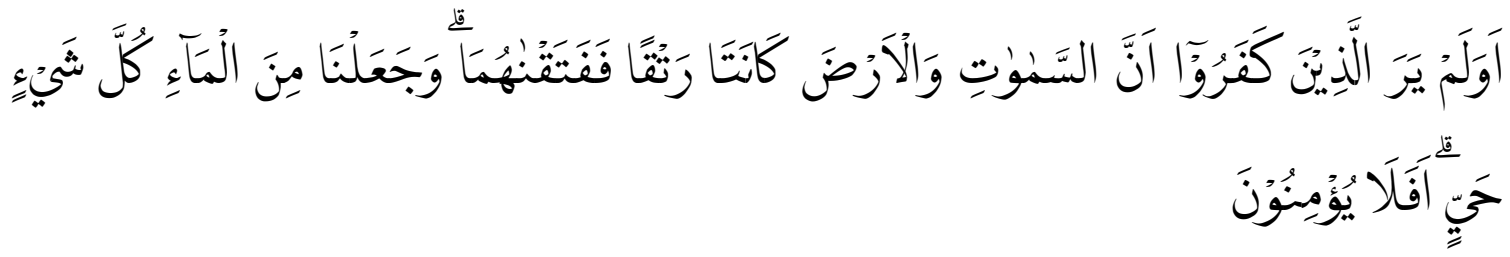

Dan apakah orang-orang kafir tidak mengetahui bahwa langit dan bumi keduanya dahulunya menyatu, kemudian Kami pisahkan antara keduanya; dan Kami jadikan segala sesuatu yang hidup berasal dari air; maka mengapa mereka tidak beriman?

Pemisahan langit dan bumi dari suatu keadaan yang padu terjadi dengan serta merta (kun fayakun) atas perintah Allah SWT sesuai keterangan pada Surat An'am ayat 73:

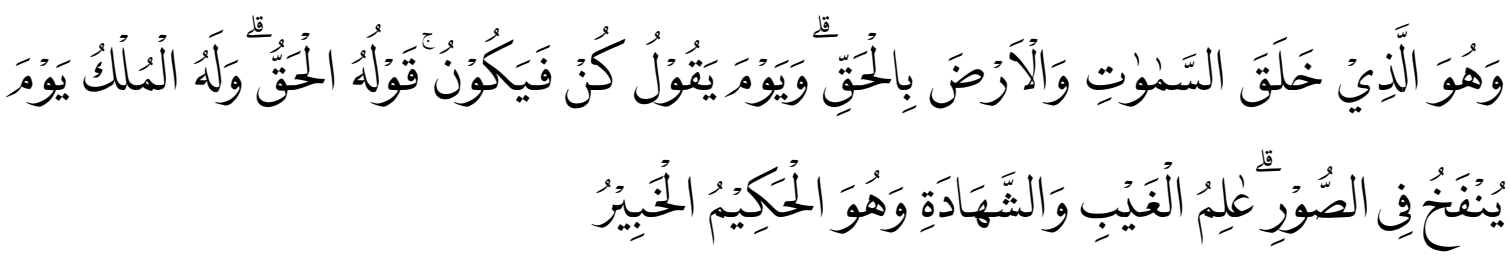

Dialah yang menciptakan langit dan bumi dengan hak (benar), ketika Dia berkata, “Jadilah!” Maka jadilah sesuatu itu. Firman-Nya adalah benar, dan milik-Nyalah segala kekuasaan pada waktu sangkakala ditiup. Dia mengetahui yang gaib dan yang nyata. Dialah Yang Mahabijaksana, Mahateliti.

Penciptaan alam semesta juga berarti mengikuti proses yang telah ditentukan oleh Allah Swt yaitu selama enam masa sesuai dengan Surat Al-A'raf ayat 54: 


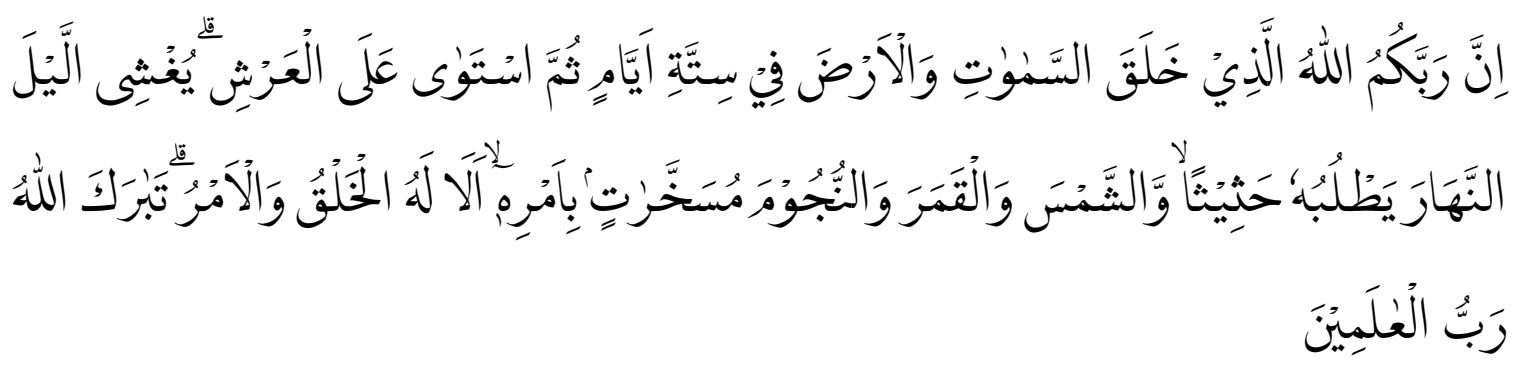

Sungguh, Tuhanmu (adalah) Allah yang menciptakan langit dan bumi dalam enam masa, lalu Dia bersemayam di atas 'Arsy. Dia menutupkan malam kepada siang yang mengikutinya dengan cepat. (Dia ciptakan) matahari, bulan dan bintang-bintang tunduk kepada perintah-Nya. Ingatlah! Segala penciptaan dan urusan menjadi hak-Nya. Mahasuci Allah, Tuhan seluruh alam.

Enam masa penciptaan langit dan bumi terdiri atas penciptaan langit dan penciptaan bumi sendiri dilakukan secara bertahap selama dua masa seperti diterangkan dalam Surat Fushilat ayat 9 dan 12, sedangkan penciptaan makhluk di muka bumi dilakukan empat masa seperti diterangkan dalam surat Fushilat ayat 10. Tahapan masa kehidupan perkembangan makhluk di bumi di jelaskan lebih rinci pada pembahasan pada penciptaan makhluk di bumi. Langit yang diciptakan oleh Allah dibangun dengan kekuasaan-Nya dan diperluas secara terus menerus sesuai dengan keterangan pada surat Adz-Dzariyat ayat 47:

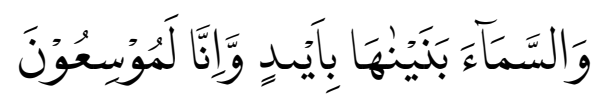

Dan langit Kami bangun dengan kekuasaan (Kami), dan Kami benar-benar meluaskannya.

Keterangan ayat tersebut didukung oleh data pengamatan yang dilakukan oleh ahli astronomi dari Amerika yang mengumpulkan dan menginterprestasikan data hasil observasi dengan menggunakan teleskopnya pada tahun 1929, bernama Edwin Huble. Ia menemukan bahwa bintang dan galaksi ternyata bergerak saling menjauh satu sama lain dengan menginterprestasi spektrum galaksi yang bergerak ke arah warna merah. Namun meluasnya alam ternyata terjadi semakin cepat. ${ }^{18}$

Apabila dikaitkan dengan sejumlah teori seputar terjadinya alam semesta menurut sains modern, maka konsep penciptaan semesta yang tertera dalam Al-Qur'an tidak dapat disangkal lagi kebenarannya. Ayat-ayat di atas Allah menganjurkan kepada hamba-Nya untuk melihat dan memikirkan fenomena alam, dan dengan melihat keteraturan dan koordinasi di dalam system penciptaan dan koordinasi di dalam sistem penciptaan dan keajaiban-keajaibanya akan lebih mendekatkan kepada-Nya. Diharapkan melalui pengetahuan tentang alam, akan melihat kebesaran Allah sebagai pencipta. Pengakuan ini

\footnotetext{
${ }^{18}$ Ridwan Abdullah Sani, Sains Berbasis Al-Qur'an, (Jakarta: 2015), 174.
} 
diikuti dengan mematuhi perintah Allah dan menjauhi larangan-Nya agar manusia tidak melakukan kerusakan di muka bumi.

\section{Tujuan Penciptaan Alam}

Tujuan penciptaan alam semesta menurut perspektif Islam pada dasarnya adalah sarana untuk menghantarkan manusia pada pengetahuan dan pembuktian tentang keberadaan dan kemahakuasaan Allah 14 Sebagaimana firman Allah swt dalam surat alDukhan ayat 38-39:

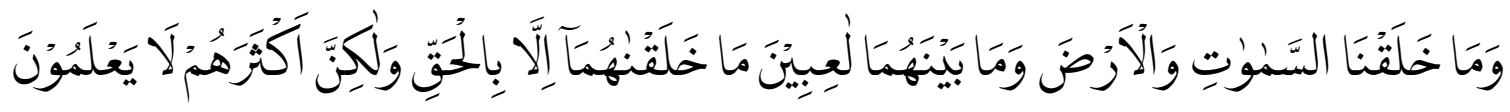

Dan tidaklah Kami bermain-main menciptakan langit dan bumi dan apa yang ada di antara keduanya. Tidaklah Kami ciptakan keduanya melainkan dengan haq (benar), tetapi kebanyakan mereka tidak mengetahui.

Al-Qur’an secara tegas menyatakan bahwa tujuan penciptaan alam semesta ini adalah untuk memperlihatkan kepada manusia akan tanda-tanda Allah Swt. Menurut Oliver Leaman, Allah merancang alam serta seluruh ciptaan-Nya adalah untuk kepentingan kita manusia, meskipun Dia tidak harus berbuat seperti itu, dan apa yang Dia minta sebagai tindak balasan-Nya hanyalah menyembah dan bertakwa kepada-Nya. Keberadaaan alam semesta merupakan petunjuk yang jelas tentang keberadaaan Allah SWT. Oleh karena itu dalam mempelajari alam semesta, manusia akan sampai pada pengetahuan bahwa Allah Swt adalah Zat yang menciptakan alam semesta. Seperti firman Allah dalam Surat Al-Fushilat ayat 53 yang artinya:

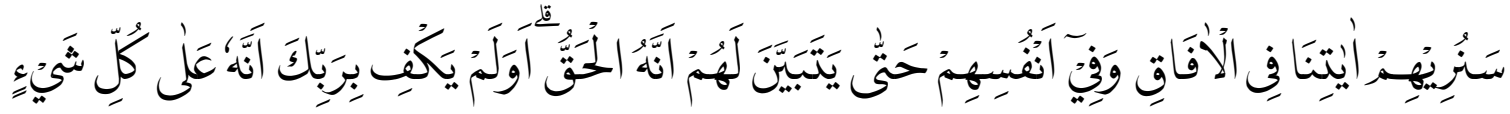

Kami akan memperlihatkan kepada mereka tanda-tanda (kebesaran) Kami di segenap penjuru dan pada diri mereka sendiri, sehingga jelaslah bagi mereka bahwa Al-Qur'an itu adalah benar. Tidak cukupkah (bagi kamu) bahwa Tuhanmu menjadi saksi atas segala sesuatu?

Ayat tersebut jelas menunjukan tanda-tanda kekuasaan-Nya. Allah yang Maha Kuasa menganjurkan kepada manusia untuk melihat dan memikirkan fenomena alam, dan dengan melihat keteraturan dan koordinasi di dalam sistem penciptaan dan keajaibankeajaibanya akan lebih mendekatkan diri kepada-Nya. ${ }^{19}$ Melalui pengetahuan tentang alam akan melihat kebesaran Allah sebagai pencipta. Pengakuan ini diikuti dengan

${ }^{19}$ Toto Suharto, Filsafat Pendidikan Islam, (Jogjakarta: AR-Ruzz Media, 2006), 101-102. 
mematuhi perintah Allah agar manusia tidak melakukan kesalahan dan alam semesta ini tidak mengalami kerusakan. Dalam Surat Ar-Ruum ayat 41, Allah berfirman:

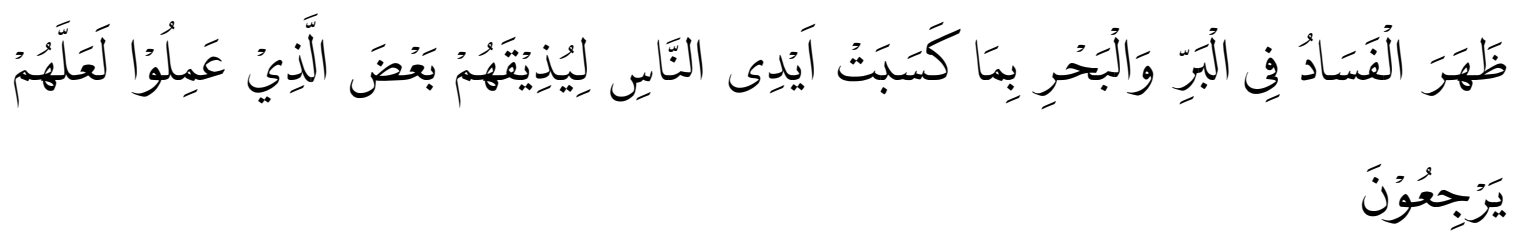

Telah tampak kerusakan di darat dan di laut disebabkan karena perbuatan tangan manusia; Allah menghendaki agar mereka merasakan sebagian dari (akibat) perbuatan mereka, agar mereka kembali (ke jalan yang benar).

Ayat tersebut menunjukan bahwa kerusakan di bumi disebabkan karena ulah tangan manusia dan pastinya akan memberikan dampak buruk kepada manusia itu sendiri. Allah swt menyebut alam sebagai nikmat besar yang diberikan-Nya untuk manusia agar dimanfaatkan dalam kehidupan di dunia secara benar. ${ }^{20}$

Manusia akan memperoleh manfaat dan keuntungan yang amat besar apabila manusia tersebut mampu dan mengerti dalam memanfaatkan apa saja yang terdapat di alam semesta ini secara bijaksana. Alam semesta diciptakan sebagai bahan dan sumber pelajaran serta pengamatan bagi manusia untuk menggali rahasia Allah Swt dengan akal dan pengamatan untuk dapat menyumbangkan suatu kebajikan dan faedah manusia seluruhnya yang pada akhirnya manusia akan memahami apa hakikat diciptakannya alam semesta ini. Hal ini tertera dalam surat Yunus: 4

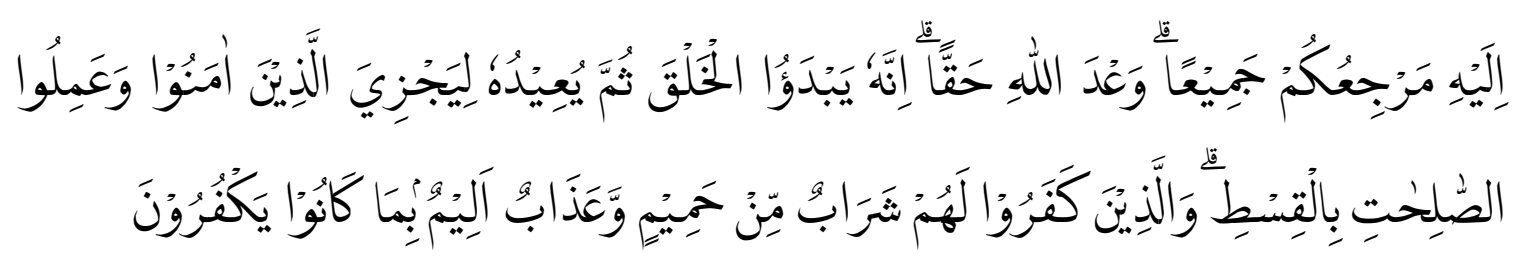

Hanya kepada-Nya kamu semua akan kembali. Itu merupakan janji Allah yang benar dan pasti. Sesungguhnya Dialah yang memulai penciptaan makhluk kemudian mengulanginya (menghidupkannya kembali setelah berbangkit), agar Dia memberi balasan kepada orang-orang yang beriman dan mengerjakan kebajikan dengan adil. Sedangkan untuk orang-orang kafir (disediakan) minuman air yang mendidih dan siksaan yang pedih karena kekafiran mereka.

Alam semesta diciptakan Allah Swt untuk kepentingan manusia, keseimbangan antara alam dengan makhluk hidup berdampak pada kesejahteraan hidup manusia. Untuk memenuhi kebutuhan manusia selama hidup di permukaan bumi ini. Oleh karenanya alam telah ditundukkan oleh Allah Swt untuk mereka, sebagai tempat tinggal bagi manusia, ini

20 Maslikhah, Alam Terkembang Menjadi Guru memotret Fenomena lingkungan Melalui Pendidikan Lingkungan Hidup, (Salatiga: STAIN Salatiga Press: 2013), 6-7. 
dimaksudkan agar manusia mudah dalam memahami alam semesta dan tahu bagaimana cara memanfaatkannya untuk kepentingan mereka.

\section{E. Pandangan Beberapa Filosof Islam Tentang Alam Semesta \\ 1. Al Ghazali}

Al-Ghazali mempunyai nama lengkap Abu Hamid bin Muhammad bin Ahmad Al-Ghozali yang lahir di Republik Islam Irak tahun $450 \mathrm{H}$ atau 1058M.18 Al Ghazali adalah seorang tokoh yang kontroversial dengan para filsuf, hal ini dibuktikan dengan kritikannya kepada para filsuf lain. Al Ghazali juga pernah menulis buku yang berjudul Al-Maqasid Al filasifah, kemudian melengkapinya dengan menulis buku keduanya yang berjudul Tahafutul Falasifa (ketidak beresan, kekaburan dari filsafat, yang lazimnya diterjemahkan dengan penghancuran filsafat). ${ }^{21}$ Kitab Tahafut Al Falasifah tersebut terdiri dari 20 diskusi yang merupakan ajaran falsafah yang berbentuk semacam dialog tertulis diikuti bantahan-bantahan. Dari 20 persoalan filsafat yang ia tulis pada kitab tersebut hanya ada 4 yang disebutkan secara langsung tentang alam semesta seperti

a) Persoalan tentang sanggahan atas pandangan para filsuf tentang eternitas alam;

b) Masalah penolakan terhadap keyakinan para filsuf atas keabadaian alam;

c) Masalah ketidakjujuran para filsuf bahwa tuhan adalah pencipta alam dan penjelasanbahwa ungkapan tersebut hanya bersifat metaforis;

d) Penjelasan tentang ketidakmampuan para filsuf membuktikan eksistensi pencipta alam.

Timbulnya reaksi dan perdebatan tentang qadimnya alam tersebut bermula dari kesimpulan para filsuf yang mengatakan bahwa alam itu qadim. Seperti Al-Farabi dan Ibnu Sina yang mengatakan bahwa alam itu qadim sedikitpun tidak dipahami mereka sebagai alam yang ada dengan sendirinya. Alam itu qadim justru Tuhan menciptakanya sejak azali. Bagi mereka mustahil Allah Swt ada dengan sendirinya tanpa mencipta pada awalnya, kemudian menciptakan alam. Hal tersebut disanggah oleh Al-Gazali dengan mengatakan bahwa qadimnya alam membawa kepada kekufuran, ketika alam itu qadim, maka alam itu tidak bemula dan ada dengan sendirinya. Ketika alam semesta ini qadim dan Allah juga qadim menyebabkan ada dualisme yang qadim, dan ini bertentangan dengan akidah Islam, yang berujung pada kemusrikan atau politeisme.

Al Ghazali kembali mengkoreksi kepada faham yang lebih umum. Selanjutnya dia mengkritik sejumlah dalil-dalil lain bukan sebagai suatu kekufuran, melainkan sebagai suatu bid'ah dan tidak logis. Dalam diskusi, Al-Gazali melawan ajaran ta'til dari mutazilah dan falsafah yang meniadakan adanya sifat-sifat nyata pada Tuhan.

Al-Gazali juga menulis dalam beberapa argumen lain dengan memperbincangkan bukti tentang keberadaan Tuhan, ke-Esaan Tuhan, pengetahuan Tuhan, penciptaan dan persoalan mengenai jiwa manusia. Al-Gazali juga menentang pernyataan yang lahir

${ }^{21}$ Yaya Sunarya, Pengantar Filsafat Islam, (Bandung: Arfino Raya,2012). h. 87 
dari filsafat Aristotelian bahwa alam adalah kekal. Menurutnya, alam berasal dari ketiadaan menjadi "ada" karena ciptaan Tuhan. Dunia berasal dari iradat (kemauan) Tuhan semata-mata dan tidak bisa terjadi dengan sendirinya. Iradat Tuhan bersifat mutlak dan terlepas dari ruang dan waktu, namun ciptaan Tuhan (dalam hal ini dunia/alam) dapat ditangkap oleh akal manusia, karena dunia terbatas dalam ruang dan waktu.

Tuhan bersifat transenden, namun kemauan (iradat) Tuhan adalah immanent dan merupakan sebab hakiki dari segala kejadian. Baginya hanya Allah yang qadim, artinya adanya Allah tidak diawali dengan tidak ada. Maka syahadat dalam teologi Islam adalah "La qadima illallah", tidak ada yang qadim selain Allah. ${ }^{22}$ Adanya alam diawali dengan tidak ada sehingga alam tidak qadim. Karena adanya adanya alam di ciptakan oleh Allah. Berdsarkan diskripsi tersebut Al-ghozali menampilkan sebuah koreksi yang berlandaskan pada Al-Qur'an diantaranya Surat Asy-Syura ayat 29 yang artinya:

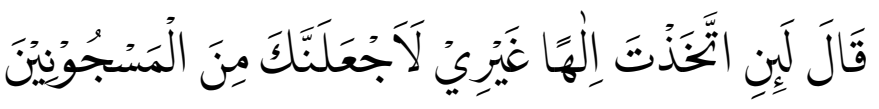

Dia (Fir'aun) berkata, "Sungguh, jika engkau menyembah Tuhan selain aku, pasti aku masukkan engkau ke dalam penjara."

QS. Az-zumar ayat 62

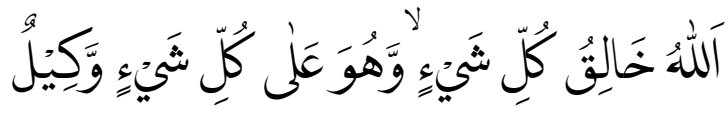

Allah pencipta segala sesuatu dan Dia Maha Pemelihara atas segala sesuatu.

QS. Al-Hasyr ayat 24

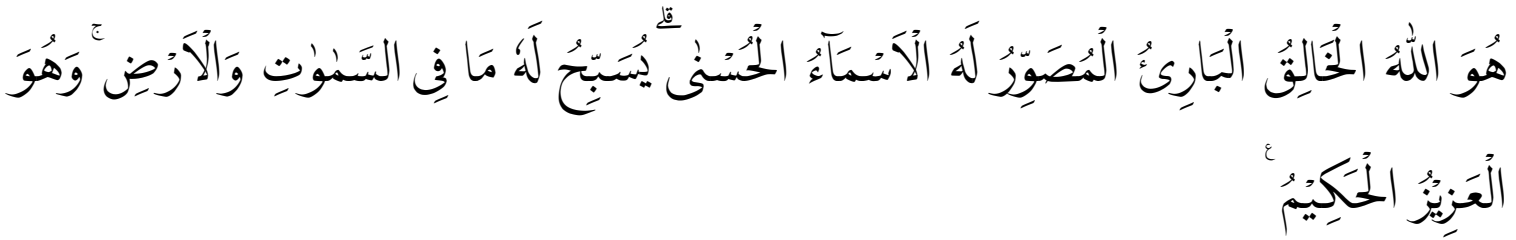

Dialah Allah Yang Menciptakan, Yang Mengadakan, Yang Membentuk Rupa, Dia memiliki nama-nama yang indah. Apa yang di langit dan di bumi bertasbih kepada-Nya. Dan Dialah Yang Mahaperkasa, Mahabijaksana.

Adanya alam adalah hasil dari iradat Tuhan, karena sifat iradat dalam pandangan Al-Gazali adalah sifat yang mutlak ada pada Tuhan, dengan kata lain, Tuhan memiliki kehendak dengan kebebasan yang tidak terbatas. Dia berkehendak untuk menciptakan atau

${ }^{22}$ Yaya Sunarya, Pengantar Filsafat. ... 97 
tidak menciptakan. Namun demikian, meskipun pandangan dan pemikiranya bersumber pada Alquran tetap saja tidak luput dari kritikan.

Seperti kritikan Ibnu Rusyd terhadap konsep Al-Gazali tentang alam hadis, bahwa alam mempunyai permulaan dalam zaman mengandung arti bahwa ketika Tuhan menciptakan alam tidak ada sesuatu disamping Tuhan. Tuhan dengan kata lain, ketika itu berada dalam kesendirianya. Tuhan menciptakan dari tiada menjadi nihil. Konsep tersebut kata Ibnu Rusyd tidak sesuai dengan kandungan Al-Qur'an. Di dalam Al-Qur'an digambarkan bahwa sebelum alam diciptakan Tuhan, Telah ada sesuatu disampingn-Nya. Penggalan Ayat 7 dari Surat Hud.

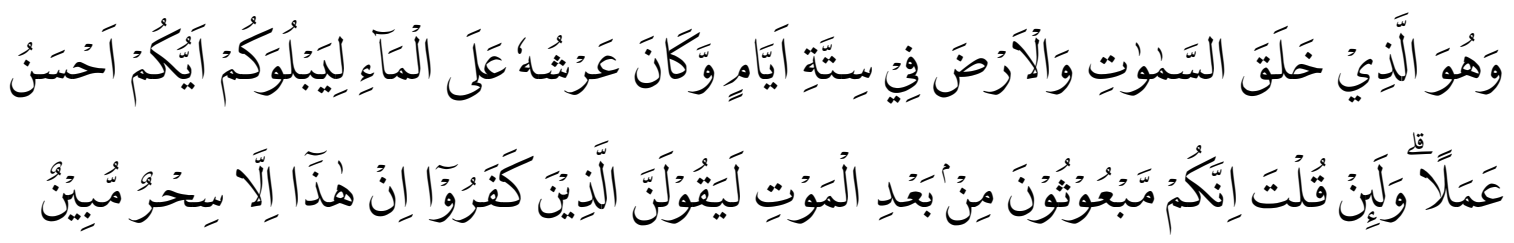

Dan Dialah yang menciptakan langit dan bumi dalam enam masa, dan 'Arsy-Nya di atas air, agar Dia menguji siapakah di antara kamu yang lebih baik amalnya. Jika engkau berkata (kepada penduduk Mekah), "Sesungguhnya kamu akan dibangkitkan setelah mati," niscaya orang kafir itu akan berkata, "Ini hanyalah sihir yang nyata."

Jelas disebut dalam ayat tersebut, bahwa Tuhan menciptakan langit dan bumi telah ada unsur lain disamping Tuhan,yaitu air. Didsamping itu kata Khalaqa di dalam AlQuran, kata Ibnu Rusyd menggambarkanpenciptaan bukan dari tiada (creatio ex nihilo) seperti yang dikatakan Al-Gazali, tetapi dari ada, seperti yang dikatakan para filsuf. Contohnya adanya bumi dan langit "ada" yang berasal dati bentuk materi asal yang empat (api, uadara, air dan tanah) diubah Tuhan menjadi "ada" dalam bentuk bumi dan langit. Dan yang kodim adalah materi yang asal. Adapun langit dan bumi susunanya adalah yang baru (hadis)

\section{Ibnu Rusyd}

Ibnu Rusyd memiliki nama lengkap Abu Al-Walid Muhammad bin Ahmad bin Muhammad bin Rusyd yang lahir di Cordova tahun 520 H/1126M. Ibnu Rusyd adalah orang yang sangat radikal mengenai filsafat alam dan banyak menimbulkan salah pengertian di kalangan ahli-ahli pengetahuan dan kaum agama. Mereka menuduh bahwa Ibnu Rusyd adalah seorang materialis, ateis dan naturalis yang tidak percaya akan Tuhan. Adapun pokok-pokok pikiran Rusyd yang di kemukakan dalam buku-buku komentarnya terhadap filsafat Aristoteles dan buku "Tahafut Al-falasifah", adalah sebagai berikut:

a) Alam semesta terdiri atas benda dan bentuk yang pada hakikatnya bersifat azali atau kekal abadi, tetapi keazalianya berbeda jauh dari azalinya Allah Swt;

b) Sifat khusus bagi alam adalah "gerak", dan karenanya memerlukan adanya "penggerak", yaitu Allah, yang bergerak adalah alam dan yang menggerakan 
adalah Allah Swt. Gerakan itulah yang menimbulkan perubahan sepanjang zaman yang tiada henti;

c) Setiap benda diliputi oleh waktu dan tempat yang tidak akan habis bahkan waktu dan benda itu termasuk alam juga, yang adanya mendahului alam benda;

d) Antara Allah Swt dengan alam semesta terdapat seperti halnya hubungan negara dengan kepala Negara, karena kedudukan-Nya sebagai pencipta maka Allah itu berbeda dengan cosmos atau alam semesta;

e) Penghubung utama antara Allah Swt dengan alam ialah intellegensia, yang bertingkat, seperti susunan bintang-bintang di langit.

Sesuai dengan keyakinan kaum teolog Muslim, Alam diciptakan Allah dari tidak ada menjadi ada, sementara itu menurut filsuf muslim, alam ini Kadim yang artinya alam ini diciptakan dari sesuatu materi yang sudah ada. Ibnu Rusyd dalam mendukung pendapat ahli filsuf yang lain ia mengemukakan sejumlah ayat Al-Qur'an diantaranya sebagai berikut:

a) Surah. Hud ayat 7 yang artinya: Dan Dialah yang menciptakan langit dan bumi dalam enam masa, dan 'Arsy-Nya di atas air, agar Dia menguji siapakah diantara kamu yang lebih baik amalnya. Jika engkau berkata (kepada pendusuk Mekah). Sesungguhnya kamu akan dibangkitkan setelah mati, niscaya orang kafir itu akan berkata, ini hanyalah sihir yang nyata;

b) Surah Al-Anbiya': 30, yang artinya: "Dan apakah orang-orang kafir tidak mengetahui bahwa langit dan bumi keduanya dahulu menyatu, kemudian kami pisahkan antara keduanya dan kami jadikan segala sesuatu yang hidup berasal dari air, maka mengapa mereka tidak beriman?

c) Surah Fussilat ayat 11 yang artinya: Kemudian Dia menuju langitdan (langit) itu asih berupa asap, lalu dia berfirman kepadanya dan kepada bumi, datanglah kamu berdua menurut perintah-Ku dengan patuh atau terpaksa. Keduanya menjawab, kami datang dengan patuh.

Menurut Ibnu Rusyd perbedaan diantara mereka disebabkan dalam memberi arti al-hadis dan qadim. Menurut kaum teolog muslim, Al-hadis berarti menciptakan dari tiada menjadi ada, sedang kan menurut kaum filsuf muslim berarti mewujudkan dari ada menjadi ada dari bentuk lain. ${ }^{23}$ Qadim menurut kaum teolog muslim adalah sesuatu yang mempunyai wujud tanpa sebab, sedangkan menurut kaum filsuf muslim adalah sesuatu yang kejadianya dalam keadaan terus menerus tanpa awal adan akhir. Dalam Fasl AlMaqal, Ibnu Rusyd menjelaskan bahwa perselisihan antara mereka tentang alam ini hanyalah perselisihan dari segi penanaman atau semantik. Mereka membagi bahwa yang ada ini terbagi menjadi tiga:

a) Jenis pertama, wujudnya karena sesuatu yang lain dan dari sesuatu dengan arti wujudnya ada pencipta dan diciptakan dari benda serta didahulii oleh zaman. Wujud ini mereka namakan dengan baru;

${ }^{23}$ Ibnu Rusyd.Tahafut, Tahaqiq Sulaiman Dunya, (Kairo: Dar Al-Maarif,1971), 362 
b) Jenis kedua, wujudnya karena tidak ada sesuatu, tidak pula dari sesuatu dan tidak didahului oleh zaman. Wujud ini mereka sepakat dan dinamakan dengan qadim. Wujud yang qadim inilah yang dinamakan dengan yang Allah.

c) Wujud yang ketiga adalah wujud yang berda di tengah-tengah kedua jenis di atas, yaitu wujud yang tidak terjadi bersal dari sesuatu dan tidak dapat di dahului oleh zaman,tetapi terjadinya karena sesuatu yang diciptakan. Wujud jenis ini adalah alam semesta. Wujud alam ini ada kemiripanya dengan jenis wujud yang pertama dan kedua. Di katakan mirip dengan yang pertama karena wujudnya dapat dilihat oleh panca indra, dan dikatakan seperti wujud yang kedua karena tidak didahului oleh zaman dan adanya sejak azali. ${ }^{24}$

Bagi Ibnu Rusyd, alam ini adalah qadim karena ia wujud dengan kemauan Tuhan, sedangkan kemauan-Nya tidak bisa ditolak dan tidak ada permulaan.Kadimnya alam tidak membawa pada politeisme atau ateisme karena kadim dalam pemikiran filsafat bukan hanya berarti sesuatu yang tidak diciptakan tetapi juga berarti sesuatu yang diciptakan dalam keaadaan terus menerus, mulai dari zaman yang tidak bermula pada masa lampau sampai ke zaman tak berakhir pada masa mendatang. Jadi Tuhan qadim berarti Tuhan tidak diciptakan, tetapi adalah pencipta. Dan alam kadim berarti alam di ciptakan dalam keadaan terus menerus dari zaman tak bermula ke zaman tak berakhir.

\section{Al-Kindi}

Al-Kindi lahir di Irak pada tahun 801M/185 H dengan nama lengkap Abu Yusuf Ya'kub Ibnu Ishaq Ibnu Sabbah ibn 'Imran Ibnu Ismail, Ibnu Muhammad Ibnu Asy-Sya'at ibn Qais. ${ }^{25}$ Ia adalah salah seorang filosof yang menentang bahwa alam itu kodim, ${ }^{26}$ yang didasarkan pada teori matematika dalam pandanganya mengenai alam, dan ia memastikan bahwa alam itu berakhir (mutanahin).

Dalam bukunya "Rasa'il Al-Kindi Al-Falsafiyah", menjelaskan bahwa alam ini di jadikan Tuhan dari yang tidak ada menjadi ada dan Tuhan yang mengendalikan, mengatur serta menjadikanya sebab yang lain. Ia juga mengemukakan tiga argumen, yakni gerak, zaman, dan benda. Benda menjadi ada harus ada gerak. Masa gerak menunjukkan adanya zaman. Adanya gerak tentu mengharuskan adanya benda. Mustahil kiranya ada gerak tanpa adanya benda. Ketiganya sejalan akan berakhir di sisi lain, benda memiliki tiga dimensi, yaitu panjang, lebar dan tinggi. Ketiga dimensi ini membuktikan bahwa benda tersusun, dan setiap yang tersusun tidak dapat dikatakan qadim.

Al-Kindi menolak secara tegas pandangan Aristoteles yang mengatakan bahwa alam terbatas oleh ruang, tetapi tak terbatas oleh waktu karena gerak alam seabadi penggerak tak tergerakan. ${ }^{27}$ Keabadian alam dalam pemikiran islam ditolak karena Islam

${ }^{24}$ Sirajuddin Zar, Filsafat Islam: Filosof dan Filsafatnya, (Jakarta: RajaGrafindo Persada, 2004), 228.

${ }^{25}$ M.M. Syarif, Para Filosof Muslim, (Bandung:Mizan, 1985), 67

${ }^{26}$ Ahmad Fuad Al-Ahwani, Filsafat Islam, (Jakarta: Pustaka Firdaus, 1988), 143.

${ }^{27}$ Yaya Sunarya, Pengantar Filsafat..., 88 
berpendirian bahwa alam diciptakan. Ibnu Sina dan Ibn Rusyd dituduh sebagai ateis karena menganggap bahwa alam ini kekal. Masalah ini menjadi masalah penting dalam filsafat Islam, termasuk Al-Gazali yang menyebutkan dua puluh dari sanggahan terhadap para filsuf dalam dalam Tahaful Al-falasifah.

\section{Ibnu Tufail}

Nama lengkap Ibnu Tufail adalah Abu Bakar Muhammmad Ibnu 'Abd Al-malik ibn Muhammad ibn Muhammad ibn Tufail yang lahir pada tahun 506 H/1110M di Spanyol. Menurut Ibnu Tufail alam ini qadim dan juga baru. Alam qadim karena Allah menciptakan sejak azali, tanpa tidak didahului oleh zaman. Dilihat dari esensinya, alam adalah baru kerena terwujudnya alam ( $m a$ 'lul) bergantung pada zat Allah. Pandangan Ibnu Tufail sama dengan pandangan Aristoteles yang menyatakan alam alam qadim dengan kaum ortodoks Islam yang menyatakan alam baru.

Ibnu Tufail untuk memperjelas pendapatnyamemberikan contoh sebagai berikut: sebagaimana ketika anda menggenggam sebuah benda, kemudian anda gerakan dengan tangan anda, maka benda mesti bergerak mengikuti tangan anda. Gerakan benda tidak terlambat dari segi zaman dan hanya keterlambatan di segi zat. Demikian pula alam, seluruhnya merupakan akibat dan diciptakan oleh Allah tanpa zaman. Firman Allah dalam Surah Yasin ayat 82.

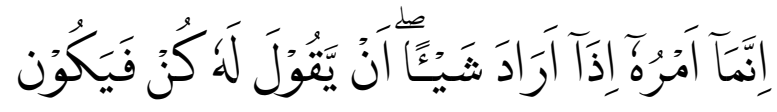

Sesungguhnya urusan-Nya apabila Dia menghendaki sesuatu Dia hanya berkata kepadanya, "Jadilah!” Maka jadilah sesuatu itu.

\section{Nasirudin Al-Tusi}

Nasirudin Al-Tusi dalam karyanya Tasawwurat (yang di tulis pada masa pemerintahan Isma'iliyyah) awalnya ia mengecam creatio ex nihilo, dengan mengemukakan bahwa dunia ini kekal karena kekuasaan Tuhan yang menyempurnakannya meski dalam hak dan kekuatanya sendiri ia tercipta.

Dalam karyanya yaitu fusul, Tusi meninggalkan sikap tersebut dan mendukung doktrin ortodoks mengenai creatio ex nihilo, pandangan yang menyatakan adanya waktu ketika dunia ini belum maujud, kemudian Tuhan menciptakannya dari yang tidak ada menjadi ada. Secara jelas mengisyaratkan bahwa Tuhan bukanlah pencipta sebelumnya adanya penciptaan dunia ini atau kekuatan penciptan-Nya masih bersifat potensial yang kemudian hari baru dapat diwujudkan, dan ini merupakan sangkalan atas daya ciptanya yang kekal.

Dengan menggolongkan zat menjadi yang pasti dan yang mungkin, dia mengemukakan bahwa eksistensi yang mungkin itu bergantung kepada yang pasti. Dan karena ia maujud akibat sesuatu yang lain dari dirinya tidak dapat dikatakan bahwa ia 
dalam keadaan maujud sebab penciptaan yang maujud itu mustahil. Dan kerena sesuatu yang maujud itu tidak ada, begitu juga kemaujudan yang pasti itu menciptakan yang mustahil itu dari ketiadaan.

Proses semacam itu disebut penciptaan, sedangkan hal-hal yang ada itu disebut yang tercipta (muhdas). ${ }^{28}$ Perdebatan yang tidak berkesudahan antara pemikiran Al-Gazali dengan Ibnu Rusyd ataupun dengan para filsuf yang lain tentang qadimnya alam semua tidak dapat dipersalahkan. Perbedaan itu wajar dan timbul karena mereka memiliki tafsiran masing-masing terhadap ayat Al-Qur'an tentang penciptaan alam. Sebab dalil-dalil yang membuktikan ke-qadimanya sama kuatnya dengan dalil-dalil yang membuktikan keabaharuan alam.

\section{PUSTAKA RUJUKAN}

A. Ahmad. Qur'anic Concept of Human Psyche. Islamabad: Islamic Research Institute Press, 1992.

A. Mujib. Fitrah \& Kepribadian Islam: Sebuah Pendekatan Psikologis. Jakarta: Darul Falah, 1999.

Abu Rayyan, Muhammad Ali. Tarikh al-Fikr al-Falsafi fil Islam. Iskandariyah, Dar alJami'at al-Mishriyah, 1984.

Al-Ahwani, Ahmad Fuad. Filsafat Islam. Jakarta: Pustaka Firdaus,1988.

Al-Ghazali. Ihya Al-Ghazali. Terjemahan Ismail Yakub. Jakarta: CV. Faizan, 1984.

Al-Qayyim. Ruh. Terjemahan Syed Ahmad Semait. Singapore: Pustaka Nasional Ltd, 1991.

Arief, Armai. Reformulasi Pendidikan Islam. Jakarta: CRSD Press, 2005.

Dewan Redaksi Ensiklopedi Islam. Ensiklopedi Islam Jiid 3. Jakarta, PT Ichtiar Baru van Hoeve, 2003.

Ibnu Rusyd.Tahafut, Tahaqiq Sulaiman Dunya. Kairo: Dar Al-Maarif,1971.

Lajnah Pentashihan Mushaf Al-Qur'an. Tafsir Al-qur"an Tematik (Spritualitas dan Ahklak). Jakarta: Aku Bisa, 2012.

M.M. Syarif, Para Filosof Muslim. Bandung:Mizan, 1985.

Maslikhah. Alam Terkembang Menjadi Guru memotret Fenomena lingkungan Melalui Pendidikan Lingkungan Hidup. Salatiga: STAIN Salatiga Press: 2013.

Mujib, Abdul. Jusuf Mudzakir. Nuansa-Nuansa Psikologi Islam. Cet. I; Jakarta: PT. Raja Grapindo Persada, 2001.

${ }^{28}$ Yaya Sunarya. Pengantar Filsafat. h. 157 
Qasim, Mahmud. Fi an-Nafs wa al- 'Aql li Falasifah al- 'Ighriq wa al-Islam, cet. IV. Kairo: Maktabah al-Injilu al-Mishriyah, 1969.

Sahroni, Jamali. Filsafat Pendidikan Islam. Bandung: 2011.

Samidi. Tuhan, Manusia, dan Alam: Analisis Kitab Primbon Atassadhur Adammakna, SHAHIH - Vol. 1, Nomor 1, Januari - Juni 2016.

Sani, Ridwan Abdullah. Sains Berbasis Al-Qur'an. Jakarta: 2015.

Satriadi, Inong. Tujuan Penciptaan Manusia dan Nilai Edukasinya (Kajian Tafsir Tematis), Ta'dib Volume. 12, No. 1 (Juni 2009).

St. Rahmatiah. KONSEP MANUSIA MENURUT ISLAM, Al-Irsyad Al-Nafs, Jurnal Bimbingan Penyuluhan Islam Volume 2, Nomor 1 Desember 2015.

Suharto, Toto. Filsafat Pendidikan Islam. Jogjakarta: Ar-Ruzz, 2006.

Sunarya, Yaya. Pengantar Filsafat Islam. Bandung: Arfino Raya,2012.

Syati, Aisyah Bintu. Manusia dalam Perspektifal-Quran, Penterjemah: Ali Zawawi, judul asli: Maqal fi al-Insan, Dirasah Quraniyyah. Jakarta: Pustaka Firdaus, 1999.

ZA, Kurdi Ismail Haji. Kiamat Menurut Ilmu Pengetahuan dan Al-Qur'an. Jakarta: Pustaka Amani, 1996.

Zar, Sirajuddin. Filsafat Islam: Filosof dan Filsafatnya. Jakarta: RajaGrafindo Persada, 2004. 